\title{
NOTOEDROSIS IN A HOUSEHOLD CAT - CASE REPORT
}

\author{
Oliver Stevanović ${ }^{1 *}$, Dejan Vujanić ${ }^{2}$, Miljan Dobrijević ${ }^{2}$, \\ Drago Nedić ${ }^{1}$, Igor Trbojević ${ }^{3}$
}

\author{
${ }^{1}$ PI Veterinary Institute of Republic of Srpska \\ „Dr Vaso Butozan“, Banja Luka, Bosnia and Herzegovina
}

${ }^{2}$ Veterinary ambulance 'BL vet' Banja Luka, Banja Luka, Bosnia and Herzegovina

${ }^{3}$ Faculty of Science University of Banja Luka, Banja Luka, Bosnia and Herzegovina

\section{Abstract}

This paper describes a rare case of severe notoedrosis (notoedric mange) in a household cat from the suburban region of Banja Luka, Bosnia and Herzegovina. According to history, the male cat was in direct contact with stray kitten which had dermatological disorder. The examination of the skin revealed an intensely pruritic and hyperkeratotic dermatitis with typical scabby appearance. Deep scarification samples were collected from the altered skin area and macerated in $10 \% \mathrm{KOH}$. The microscopic examination revealed mites from genus Notoedres, later identified as Notoedres cati according to the morphological shape and size. The affected cat was treated with ivermectin $0.4 \mathrm{mg} / \mathrm{kg}$, subcutaneously, two times with 7 day intervals. The first follow-up physical examination was done after seven days. This control showed that pruritic changes began to disappear. This case report confirms the presence of Notoedres cati in the cat population in Bosnia and Herzegovina.

Key words: household cat; Notoedres cati, Bosnia and Herzegovina;

${ }^{1 *}$ Corresponding author: oliver.13.stevanovic.bih@gmail.com 


\title{
NOTOEDROZA KOD KUĆNE MAČKE - PRIKAZ SLUČAJA
}

\author{
Oliver Stevanović1, Dejan Vujanić2, Miljan Dobrijević2, \\ Drago Nedić ${ }^{1}$, Igor Trbojević ${ }^{3}$
}

${ }^{1} J a v n a$ ustanova veterinarski institut Republike Srpske

„Dr Vaso Butozan“, Banja Luka, Bosna i Hercegovina

${ }^{2}$ Veterinarska ambulanta 'BL vet' Banja Luka, Banja Luka, Bosna i Hercegovina

${ }^{3}$ Prirodno-matematični fakultet, Banja Luka, Bosna i Hercegovina

\section{Kratak sadržaj}

Ovaj rad opisuje rijedak slučaj teške notoedroze (notoedres šuge) kod kućne mačke iz suburbanog područja Banja Luke, Bosna i Hercegovina. Prema anamnezi, mačak je bio u direktnom kontaktu sa mačetom lutalicom koje je imalo dermatološke poremećaje. Dermatološkim pregledom je ustanovljen visoko pruritični i hiperkeratotični dermatitis sa tipičnom krustoznom prezentacijom. Uzeti su skarifikati dubljih slojeva kože sa promjenjenih dijelova kože i macerirani u $10 \% \mathrm{KOH}$. Mikroskopskim pregledom su ustanovljene grinje iz roda Notoedres, koje su identifikovane kao Notoedres cati na osnovu morfologije i veličine. Oboljeli mačak je terapiran potkožno sa ivermektinom u dozi od $0.4 \mathrm{mg} / \mathrm{kg}$ dva puta, u razmaku od sedam dana. Prvi kontrolni pregled je izvršen nakon sedam dana. Već na osnovu prvog kontrolnog pregleda je ustanovljeno da su se pruritične lezije počele povlačiti. Ovaj rad potvrđuje prisustvo Notoedres cati u populaciji mačaka u Bosni i Hercegovini

Ključne riječi: kućna mačka, Notoedres cati, Bosna i Hercegovina

\section{INTRODUCTION}

Notoedrosis or notoedric feline mange is a rare but potentially fatal disease of domestic and wild felids caused by obligate sarcoptic mite species Notoedres cati (Foley et al., 2016). Members of the genus Notoedres are related to the Sarcoptes genus, but they differ with regard to some morphological characteristics such as shape or development of setae so that these traits were initially sufficient to separate mites into individual genera (Foley et al., 2016). Notoedres cati is extremely contagious, and it spreads rapidly via direct contact among cats, other mammals (hedgehogs, guinea pigs, European rabbits) and humans 
(Foley et al., 2016; Klompen, 1992). Notoedric mange was documented in dogs (Leone, 2007) but there are scarce data explaining how dogs can serve as definitive hosts for Notoedres cati or if dogs can serve as a source of infection for cats in the transmission chain. It is accepted that Notoedres cati has a cosmopolitan worldwide distribution in felid population with several reported endemic foci in North and South America; however, epidemiological studies on mite distribution and mange prevalence are scarce (Foley et al., 2016). So far, a limited number of clinical case reports indicate that Notoedres cati is present and widespread in Europe (Foley et al., 2016). In the Balkans, Notoedres cati was reported in stray cats in Slovenia (Rataj et al., 2004), Bosnia and Herzegovina (Vuković, 1959), Greece (Lefkaditis et al., 2015) and rabbits in Serbia (Ilić et al., 2018). In today's small veterinary practices, clinical cases of notoedric mange can be rarely seen because the current use of 'new' antiparasitic drugs and indoor keeping of domestic cats reduced the prevalence of this skin disease.

This case report describes clinically manifested notoedrosis (notoedric feline mange) in a household domestic cat from the suburban region of Banja Luka, Bosnia and Herzegovina.

In mid-February 2019, a male, one-year castrated domestic shorthair cat was brought to the veterinary practice „BL vet” Banja Luka for a physical and dermatological examination due to intense and frequent itching. The cat lived in a house, but it used to go outdoors regularly and was often in direct contact with other stray cats in the area of Rakovačke bare (44.796082; 17.183279), Banja Luka. According to the owner, 14 days before he went on a business trip, he noticed that the cat was in direct contact (they often lay together outside) with the stray kitten with an advanced skin disorder. Afterwards (approximately 5 - 10 days) the cat began to scratch itself constantly around the head and ears until the first lesions appeared. There was no history of vaccination and deworming of the owned cat.

The physical examination revealed good body condition and mild lethargy with normal respiration, heart rate and body temperature. Visible gingival mucosa and conjunctiva were mildly anaemic. There were indications of mild dehydration. The skin was dry and dull with the hair coat of poor quality. Alopecia and secondary scratches were present on the skin of the ears, head and face (Figure 1.). 


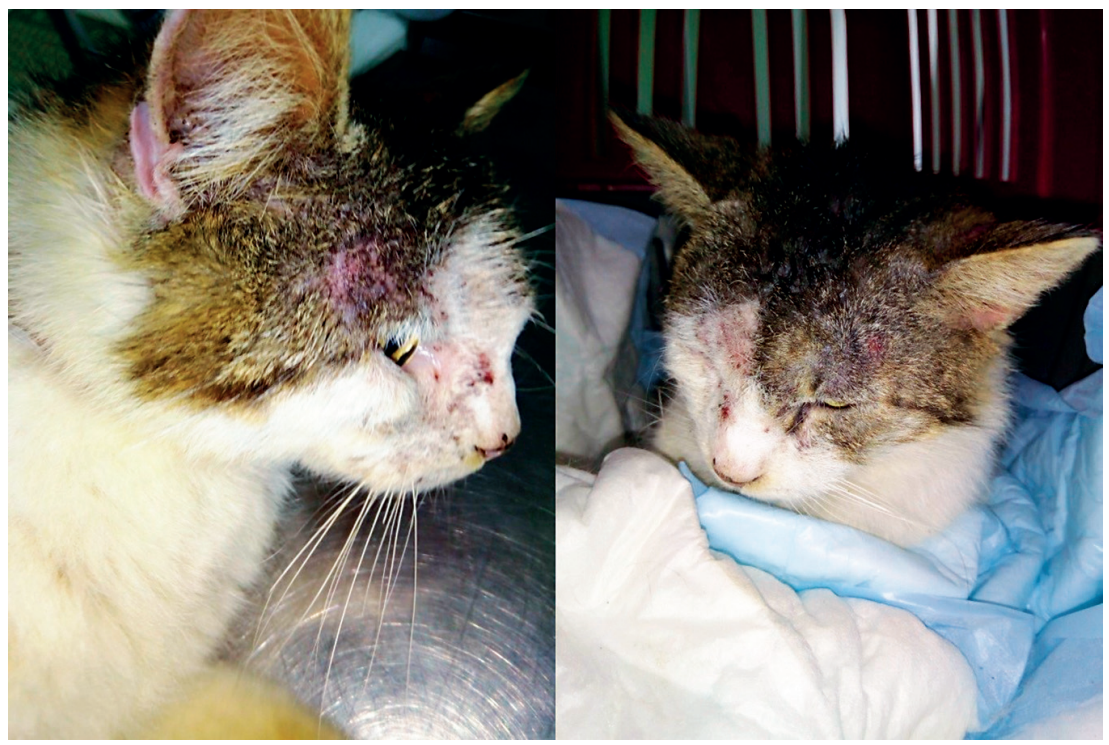

Figure 1. Pruritic head lesions in a household cat (original photos)

Due to intense pruritus, scales and crusts on the face, ear pine, head and front legs were observed. Pruritus was intense in the periocular area so that the eyes were sometimes closed during the episodes of scratching and consequent self/mutilation dermatitis. The reactive skin on the head was hyperkeratotic, hyperpigmented/grey of scabby appearance (Figure 2).

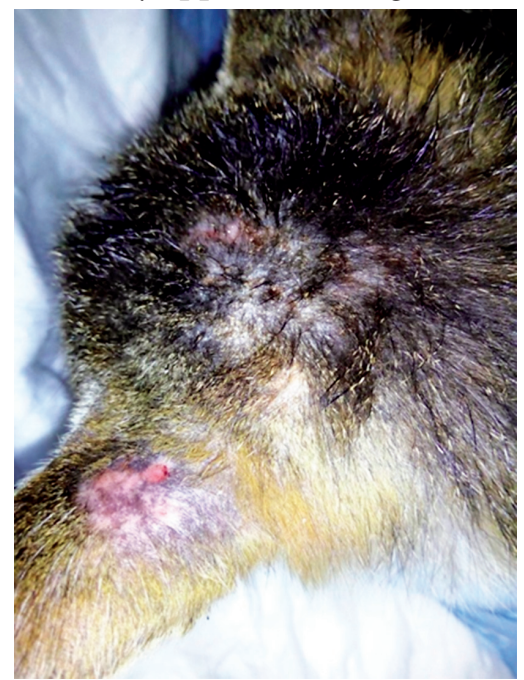

Figure 2. Hyperpigmented and hyperkeratotic changes on ear pine and head in a cat (original photo) 
After clinical and dermatological examinations, clinical suspicion to notoedric mange was established. According to Hellmann et al. (2013), skin lesions were scored as $3^{\text {rd }}$-grade ones - severe lesions affecting an area wider than the region of the head, severe alopecia, a thick/crusty and scabby appearance of the skin, intensive scratching, inducing to self-trauma injury.

Several deep skin scrapings from the altered skin area of ear pine and head were taken with a scalpel blade. The collected skin material was macerated in $10 \% \mathrm{KOH}$ (potassium hydroxide) and observed under the microscope (4x, $10 \mathrm{x}, 20 \mathrm{x}, 40 \mathrm{x})$ in the veterinary practice "BL vet". The microscopic examination revealed a high number of adults and eggs of small burrowing mites from the family Sarcoptidae. At higher magnifications, oval idiosoma with longer front legs, short pretarsi with long pedicel and terminal sucker (p), long bristle or terminal setae on the third and fourth leg were observed in female mites Tse (Figure 3).

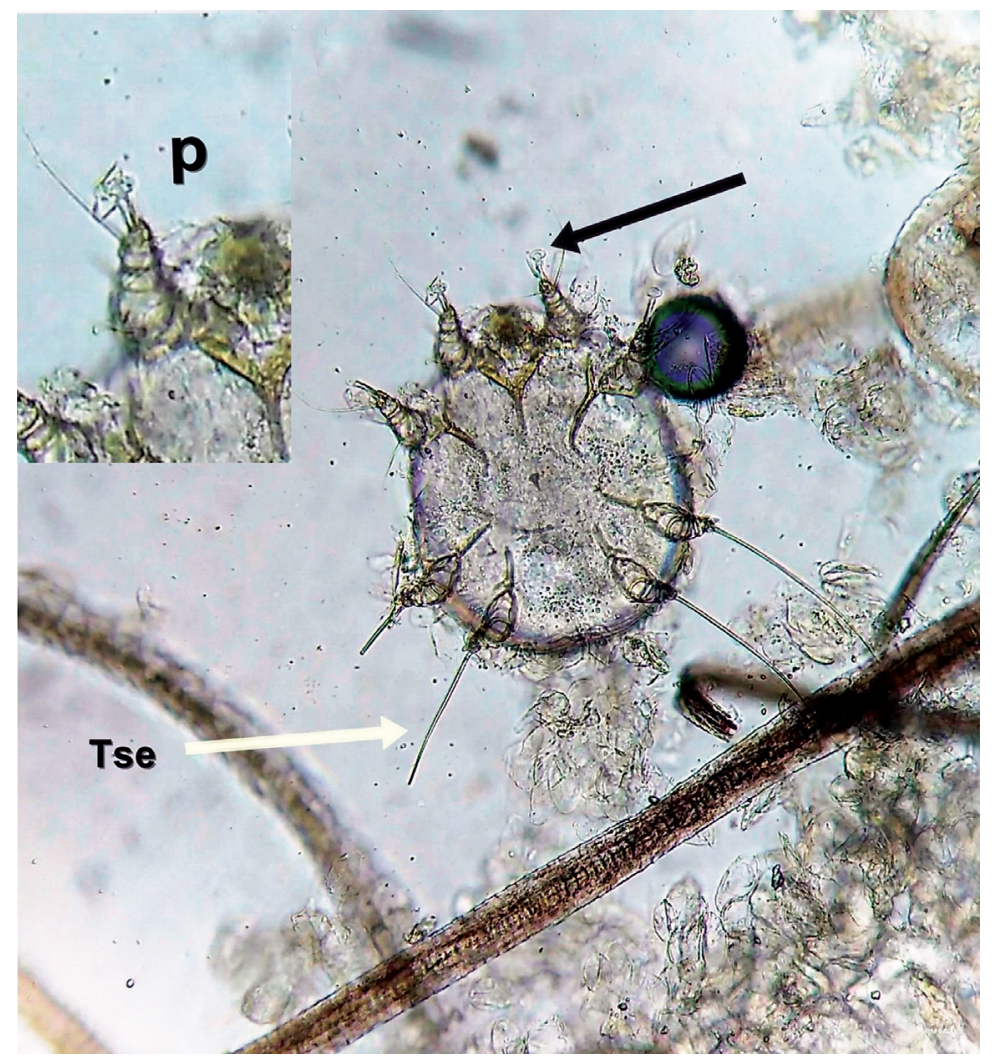

Figure 3. Ventral view of female Notoedres cati: (p) black arrow - pedicel; (Tse) white arrow - terminal setae (original photo) 
At the dorsal surface, the idiosoma had concentric, fingerprint-like striations (St), the anus surrounded by blunt spines (Sp) and dorsal setae (Se) (Figure 4). According to the morphological and morphometric examinations (Bowman, 2008; Klompen, 1992) the definitive diagnosis was Notoedres cati.

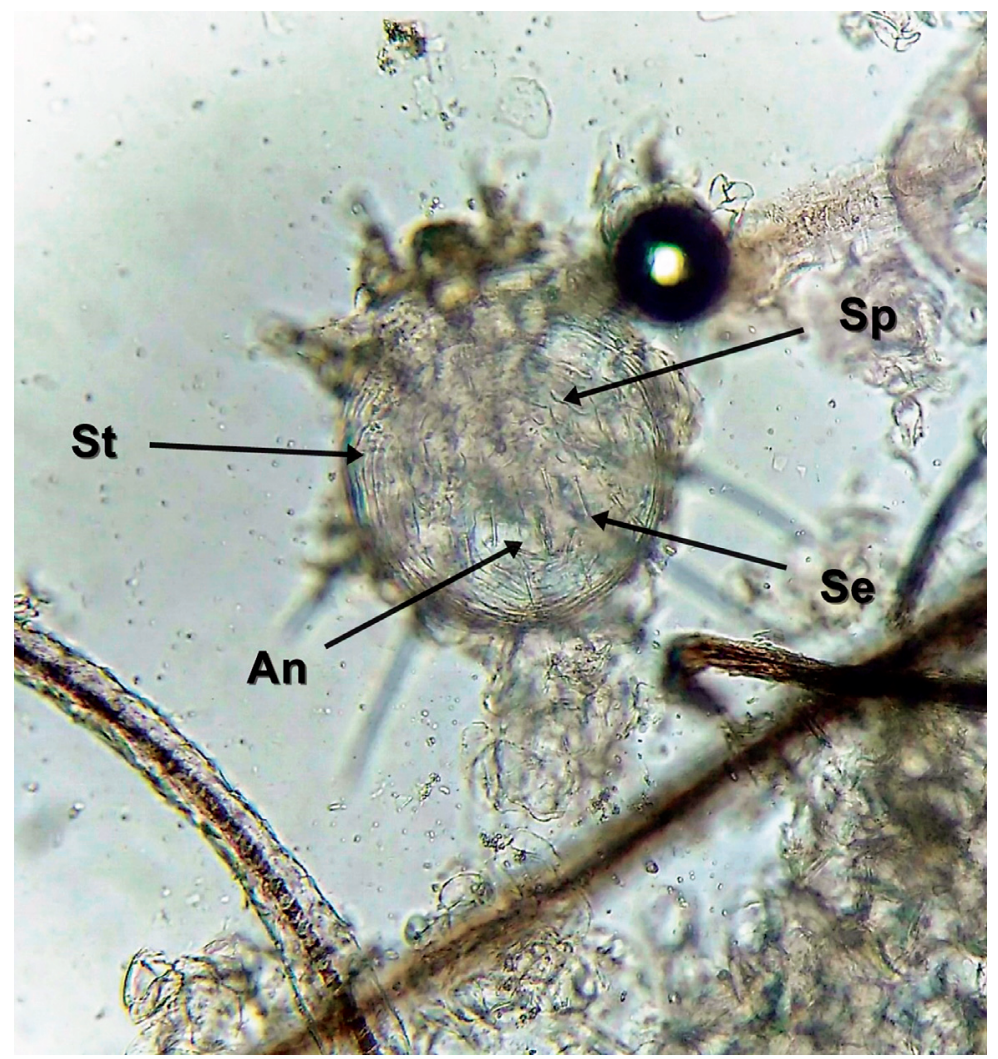

Figure 4. Dorsal view of female Notoedres cati; An - anus; Se - setae; Sp - „blunt“ spines; St - 'finger-like' striations (original photo)

The affected cat was treated with ivermectin $0.4 \mathrm{mg} / \mathrm{kg}$, subcutaneously, in 7 days intervals. In addition, dexamethasone $0.2 \mathrm{mg} / \mathrm{kg}$, intramuscularly, was administered. The first follow-up physical examination was done after the first seven days. The severe pruritus decreased and the skin lesions started to heal, and hence the treatment with ivermectin was repeated using the same dose to finishing the treatment protocol. No adverse effects of ivermectin were observed in this case. No further follow-up examinations of the cat were performed. 


\section{DISCUSSION}

The occurrence of notoedrosis in household cats is extremely rare in Bosnia and Herzegovina, as evidenced by the fact that the last written evidence of its occurrence dates back to 1959 (Vuković, 1959). In this first report, there was no precise information on the clinical impact of Notoedres cati to cats and other hosts; however, the author noticed only a low prevalence of mites in carnivores (Vuković, 1959). This report suggests that this mite species is still present in the population of domestic cats and that it can cause severe disease in cats - especially among stray animals without regular monitoring of health condition.

Given the data obtained from the anamnesis in this case, it can be assumed that the current mite infection in the cat was probably developed as a consequence of direct contact with a stray kitten. Therefore, it is possible that the disease is present in a wider area of this part of the city. In order to confirm the suspicion of potential spread of this parasite it is necessary to conduct an extensive epidemiological investigation not only in Banja Luka but in a wide area of the country.

Earlier surveys suggest that subclinical infection with Notoedres cat $i$ is possible, especially in stray cats (Rataj et al., 2004). The advanced infection found in our case is less common in the literature and the fact is that this condition, if left untreated, can cause serious health disorders and, in some cases, the death of diseased animals (Hellmann et al., 2013). The clinical manifestations of the disease described in the literature can be divided into several degrees in relation to the distribution of lesions (Hellmann et al., 2013). In the described case, the established degree of the lesion is described as extremely "difficult" and "advanced". There are several strategies for feline scabies therapy that mainly depend on the availability of active antiparasitics and the severity of the disease. The systemic use of ivermectin administered in our case was often implemented in the treatment of feline mites (Sampaio et al., 2017). It should be noted that, in the meantime, new "spot-on" formulations of safer antiparasitics based on imidacloprid 10\% / moxidectin 1\% for cats have been developed that are more accessible on markets (Hellmann et al., 2013). Ivermectin is toxic to kittens (Kirkpatrick and Megella, 1987), which must be taken into account when selecting the therapy. Supportive therapy with corticosteroids and antibiotics is justified in severe cases to reduce intense itching and prevent secondary pyoderma. Dexamethasone was applied in our case due to intense itching which could lead to self-mutilation. 
This case represents a rare description of notoedrosis in a household cat, and confirms the presence of this 'forgotten' parasite in the territory of Bosnia and Herzegovina. In daily clinical practice, deep skin scarification samples should be taken from cats with manifest pruritus and tested for the presence of Notoedres cati.

\section{Authors' contributions}

OS examined cat and diagnosed Notoedric mange, drafted first version of the manuscript; DV, MD, DN and IT drafted the final version of the manuscript

\section{Competing interest}

Authors declared no conflict of interests regarding the present paper.

\section{REFERENCES:}

1. Bowman D.D., Hendrix C.M., Lindsay D.S., Barr S.C. 2008. Feline clinical parasitology. John Wiley \& Sons, 469.

2. Foley J., Serieys L.E.K., Stephenson N., Riley S., Foley C., Jennings M., Wengert M., Vickers W., Boydston E., Lyren L., Moriarty J., Clifford D.L. 2016. A synthetic review of notoedres species mites and mange. Parasitology, 143, 1847-1861.

3. Hellmann K., Petry G., Capari B., Cvejic D., Kramer F. 2013. Treatment of naturally Notoedres cat $i$-infested cats with a combination of imidacloprid $10 \% /$ moxidectin $1 \%$ spot-on (Advocate/Advantage Multi, Bayer). Parasitol Res, 112, 57-66.

4. Ilić T., Stepanović P., Nenadović K., Dimitrijević S. 2018. Improving agricultural production of domestic rabbits in Serbia by a follow-up study of their parasitic infections. Iran J Vet Res, 19, 290-297.

5. Kirkpatrick C.E., Megella C. 1987. Use of ivermectin in the treatment of Aelurostrongylus abstrusus and Toxocara cati infection in a cat. J Am Vet Med Assoc, 190, 1309-1310.

6. Klompen J.S.H. 1992. Phylogenetic Relationships in the Mite Family Sarcoptidae (Acari: Astigmata). Museum of Zoology, The University of Michigan, 131.

7. Lefkaditis M.A., Sossidou A.V., Panorias A.H., Koukeri S.E., Pastiu A.L., Athanasiou L.V. 2015. Urban stray cats infested by ectoparasites with zoonotic potential in Greece. Parasitol Res, 114, 3931-3934. 
8. Leone F. 2007. Canine notoedric mange: a case report. Veterinary Dermatology, 18, 127-129.

9. Rataj A.V., Posedi J., Bidovec A. 2004. Ectoparasites: Otodectes cynotis, Felicola subrostratus and Notoedres cati in the ear of cats. Slov Vet Res, 41, 89-92.

10. Sampaio K.O., de Oliveira L.M., Burmann P.M., Sousa F.R.P., Evangelista J.S., Cunha M.G. 2017. Acetate tape impression test for diagnosis of notoedric mange in cats. J Feline Med Surg, 19, 702-705.

11. Vuković V. 1959. Prilog poznavanju parazitarnih oboljenja mesojeda. Veterinaria (Sarajevo), 8, 605-610.

Submitted: 06.09.2019.

Accepted: 15.11.2019. 